Revista de la Facultad de Medicina de la Universidad de lberoamérica
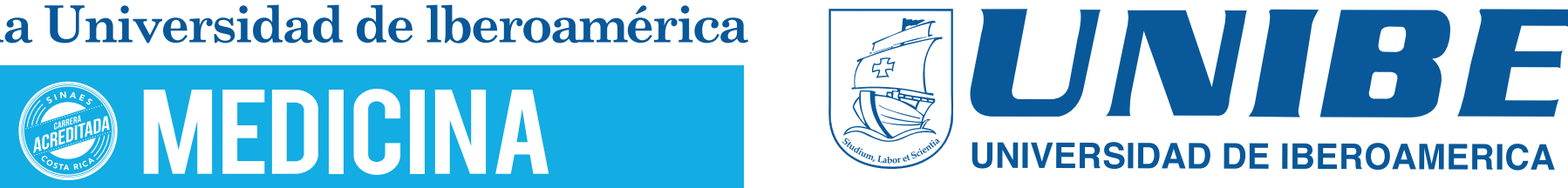

UNIVERSIDAD DE IBEROAMERICA

\title{
Artículo \\ ¿Cómo interpretar un \\ examen general de orina?
}

Dr. Juan Ignacio Padilla Cuadra 1

1.Vicedecano de Medicina

Correspondencia con: Dr. Juan Ignacio Padilla Cuadra

correo electrónico: revistamedicina@unibe.ac.cr

\section{Introducción}

El examen de orina es una prueba de uso rutinario en medicina. Esta herramienta es relativamente simple y permite hacer diagnóstico de numerosas entidades renales, urológicas y sistémicas.

Se presentan a continuación elementos fundamentales sobre este examen.

\section{Toma de la muestra}

De acuerdo con normas internacionales, lo ideal es recolectar la primera orina de la mañana. Se recomienda la recolección de la muestra en un recipiente limpio y enviarla lo más pronto posible al laboratorio para su análisis.

No es recomendable que se tarde más de 2 horas su llegada al laboratorio para su análisis ya que se distorsionará el resultado.

En caso de que sea imposible su análisis en ese plazo, se puede enfriar la muestra, sin congelar, para su preservación a $4^{\circ} \mathrm{C}$.
Para la toma de la muestra se recomienda:

- En el caso de los hombres, realizar limpieza del pene, con toallita. a nivel del meato uretral.

- En el caso de las mujeres, se deben separar los labios y realizar la limpieza con toallita, y tomar la muestra.

- No debe tocar el interior del recipiente para evitar que se contamine.

\section{Análisis macroscópico: Color}

El color normal de la orina es amarillo paja. Cambios en su coloración pueden deberse a contaminantes o enfermedades específicas.

Algunos ejemplos de colores anormales:

- Café: pigmentos biliares, mioglobinuria, metronidazole, nitrofurantoina, antimalaricos.

- Verde: Infección por pseudomonas, azul de metileno, cimetidina, amitriptilina.

- Naranja: Pigmentos biliares, fenotriazina, fenazopiridina.

- Rojo: Hematuria, hemoglobinuria, rifampicina, ingesta de remolacha.

- Amarilla: orina concentrada, ingesta de zanahoria. 


\section{Olor}

Algunas situaciones clínicas pueden causar olor de la orina característico. Tal es el caso de:

- Olor a alcohol: en intoxicación por etanol

- Olor amoniacal: cuando hay infección por bacterias que descomponen la urea.

- Olor a frutas: es característico de la cetonuria

- Olor fecaloide: cuando hay fistula entero-vesicales

\section{Análisis rutinario}

Cada vez que se solicita un examen general de orina se hacen las siguientes determinaciones:

- $\mathrm{pH}$

- Densidad urinaria

- Glucosa

- Cuerpos cetónicos

- Proteínas

- Bilirrubina

- Esterasa leucocitaria

- Nitritos

- Conteo leucocitario

- Conteo eritrocitario

- Urobilinógeno

- Densidad urinaria

- Cilindros

Detallamos a continuación cómo se interpretan cada uno de estos hallazgos.

\section{pH}

normalmente la orina mantiene un rango entre 5.5 a 6.5 en la primera muestra de la mañana. Un pH muy acido (menor a 7) sugiere acidosis metabólica, insuficiencia renal y acidosis tubular renal. Si el pH es mayor a 7, alcalino, se pude deber a alcalosis metabólica, diuréticos o alcalosis respiratoria por hiperventilación.

Recuerde que una orina alcalina en una infección del tracto urinario sugiere gérmenes productores de ureasa.

\section{Densidad Urinaria}

El valor normal es de 1016-1022. De manera práctica, podemos decir que si el valor es menor a 1010 hay relativa hidratación y mayor a 1020 se debe sospechar deshidratación. En estados de deficiencia de hormona antidiurética, la densidad es baja.

\section{Proteínas}

No debe haber cantidades importantes de proteína en orina. En general, deben ser menores a $10 \mathrm{mg} / \mathrm{dl}$. Se define proteinuria si hay más de $150 \mathrm{mg}$ por día en la orina. La microalbuminuria se define cuando la excreción de proteína oscila entre 30 y $150 \mathrm{mg} /$ día. La presencia de proteína en orina en cantidad exageradas puede indicar lesión a nivel glomerular como el caso del síndrome nefrótico (pérdida de proteínas vía urinaria mayor 3.5 gramos por día).

\section{Glucosa}

La Glucosa normalmente filtrada y prácticamente totalmente absorbida.

Aparece glucosa en orina (glucosuria) cuando se sobrepasa el umbral de reabsorción tubular) 180 a $200 \mathrm{mg} / \mathrm{dl}$ ).

Ejemplos de esto son diabetes mellitus y síndrome de Cushing.

\section{Cuerpos cetónicos}

La aparición de cuerpos cetónicos puede ser el resultado de descompensación diabética pero también debido a ayuno, embarazo y dieta rica en carbohidratos.

Nitritos. La degradación de nitratos a nitritos por parte de bacterias puede producir la aparición de estas sustancias en la orina.

Aunque es útil, no necesariamente sino aparece no descarta infección. 


\section{Esterasa leucocitaria}

Esta sustancia es producida por neutrófilos y por tanto un parámetro para sospechar infección.

\section{Bilirrubina y urobilinógeno}

La bilirrubina no conjugada no atraviesa la membrana glomerular. Sin embargo, la bilirrubina conjugada si pasa el glomérulo.

El urobilinógeno es reabsorbido hacia la circulación portal y una pequeña parte es filtrado por el glomérulo. Este se encuentra aumentado en la orina de pacientes con enfermedades hepatocelulares y en anemias hemolíticas.

\section{Análisis microscópico}

Para análisis la orina al microscopio, la muestra debe centrifugar a 1500-3000 rpm por 5 minutos. El conteo leucocitario normal, en hombres, es de menos de 2 células por campo... En mujeres se acepta hasta 5 células por campo.

Las células epiteliales aparecen normalmente en la orina y son de bordes irregulares y núcleos pequeños. La aparición de células redondeadas indica patología tubular. Normalmente hay menos de 2 eritrocitos por $\mathrm{ml}$. Se define hematuria por la presencia de tres o más eritrocitos por campo. Debe destacarse que la hematuria puede originarse en tres sitios:

Los cilindros urinarios permiten localizar el sitio de la lesión de tracto urinario. Están formados de una microproteína llamada de Tamm-Horsfall a la que se añaden elementos celulares. Los cilindros pueden ser de varios tipos:

- Hialinos se asocian a pielonefritis y falla renal crónica

- Eritrocitarios presentes en glomerulonefritis

- Leucocitario en pielonefritis, glomerulonefritis y nefritis intestinal

- Epiteliales en necrosis tubular aguda

- Granulares en falla renal avanzada

- Grasos en síndrome nefrótico.

\section{¿Cómo se interpreta la bacteriuria?}

Normalmente, no debería haber bacterias en la orina. En las mujeres, la presencia de 5 o más bacterias por campo indica 100000 o más unidades formadoras de colonias. En paciente sintomáticos, una cantidad tan baja como 100 unidades formadoras de colonias requiere tratamiento.

\section{Conclusión}

El examen de orina es una herramienta útil, fácilmente disponible y de rápida interpretación que permite diagnóstico y seguimiento de numerosas entidades clínicas.

\section{Lecturas Recomendadas}

1. Campuzano Maya G, Arbelaez Gomez M. El uroanálisis: Un gran aliado del médico. Revista Urología Colombiana 2007: 16 (1): 67-92.

2. Laso MC. Interpretación del análisis de orina. Arch Argent Pediatr 2002; 100 (2): 179-183. 